\section{Low-stringency PCR Provides an Internal Control for Negative Results in PCR-based Diagnosis}

\author{
Otávia Luisa S. Damas de \\ Caballero, 1,2,3 Emmanuel \\ Dias Neto, ${ }^{1}$ Matilde Cota \\ Koury, ${ }^{3}$ Alvaro J. Romanha, \\ and Andrew J.G. Simpson ${ }^{1}$
}

'Centro de Pesquisas "Rene Rachou", FIOCRUZ, Belo Horizonte 30190-002

Minas Gerais, Brazil; ${ }^{2}$ Departamento de Ciências Biológicas, Faculdade de Medicina do Triângulo Mineiro, Uberaba 38015-050 Minas Gerais, Brazil; ${ }^{3}$ Departamento de Microbiologia, Instituto de Ciências Biológicas, Universidade Federal de Minas Gerais, Belo Horizonte 31270 Minas Gerais, Brazil
There is widespread interest in the application of PCR for the diagnosis of infectious diseases. The overriding concern in the application of this undoubtedly powerful technique lies in adequately controlling both positive and negative results so that high throughput protocols can be used with confidence. In the case of false negatives, the currently used approaches include multiplex amplification, where an additional pair of primers is added that are specific for a host gene, ${ }^{(1)}$ or the addition of an engineered control template that produces a product of different size from that of the authentic DNA fragment with the same pair of primers. ${ }^{(2)}$ Neither of these approaches offers a true internal control for negative results. In the former case, the two amplifications are quite distinct with different efficiencies. Furthermore, there is no control for the omission of one or both primers that amplify the target DNA. In the latter case, a quite separate template is required and there is no control for the inadvertent omission of the sample DNA being tested. In both cases, a relatively common outcome is the amplification of the test but not the control fragment. ${ }^{(2)}$ The ideal internal control to assure accuracy of negative results would be the amplification of different sets of products from the sample by the same specific primer pair, depending on the presence or absence of the specific DNA. This is the case when the specific PCR primers are used under low-stringency conditions [low-stringency PCR (LSPCR) $]^{(3)}$ This protocol results not only in the amplification of the specific DNA sequence defined by the primers when present in the sample but also in a further set of low-stringency products (LSPs) irrespective of the presence or absence of the test sequence. The LSPs are the result of partially mismatched priming events throughout the DNA present in the reaction and are analogous to the DNA fragments that are produced in the generation of random amplified polymorphic DNAs (RAPDs). ${ }^{(4,5)}$

To test LS-PCR in the context of diagnosis, we have chosen to use leptospirosis as a model system. Leptospirosis can be fatal and is easily confused with other acute bacterial infections. Typically, following a short latent period of between 2 and 14 days, there is a pronounced but transient leptospiremia of up to 10,000 bacteria/ml that results in the typical symptoms of acute bacterial infection.
For treatment to be effective, it must be administered during this phase of the disease. However, there is no detectable antibody present during this phase, and the direct microscopic detection of the organism is extremely difficult owing to the low numbers of organisms in some cases and the transient nature of the leptospiremia. Diagnosis based on culture is ruled out because of the extremely slow growth of the organism. ${ }^{(6)}$ Thus, PCR is of great potential value in the timely diagnosis of this infection.

\section{MATERIALS AND METHODS}

Leptospira interrogans was cultured in the liquid medium of Ellinghausen and McCullough, as modified by Johnson and Harris ${ }^{(7)}$ for 7 to 10 days under aerobic conditions in the dark at $28^{\circ} \mathrm{C}$. During the exponential growth phase, the organisms were centrifuged at $13,000 \mathrm{~g}$ for $30 \mathrm{~min}$ at $4^{\circ} \mathrm{C}$, and the pellet was washed twice in PBS and stored at $-70^{\circ} \mathrm{C}$ until use. Experimental infections were undertaken by infecting Golden hamsters intraperitoneally with $2 \times 10^{5}$ bacteria. Blood samples $(0.5 \mathrm{ml})$ were taken daily from which the serum was separated and any bacteria present collected by centrifugation at $13,000 \mathrm{~g}$ for $30 \mathrm{~min}$ at room temperature.

Total DNA from cultured or serumderived bacteria was prepared by cell lysis and overnight incubation in SDSproteinase $\mathrm{K}$, followed by extraction with phenol-chloroform and ethanol precipitation as described by Tamai. ${ }^{(8)}$ The DNA was resuspended in TE and stored at $4^{\circ} \mathrm{C}$. The concentration of DNA prepared from cultured bacteria was determined by electrophoresis against known standards and the amounts indicated in the text used for amplification. The DNA from serum samples was resuspended in $60 \mu \mathrm{l}$ of TE, and $1 \mu \mathrm{l}$ was used for amplification.

LS-PCR was undertaken with the primers described previously by Gravekamp $^{(9)}$ for the specific diagnosis of Leptospira: G1 $=5^{\prime}$-CTGAATCGCTGTATAAAAGT- $3^{\prime}$ and G2 $=5^{\prime}$-GGAAAACAAATGGTCGGAAG- $3^{\prime}$. A reaction volume of $10 \mu \mathrm{l}$ was used for all amplifications containing $200 \mu \mathrm{M}$ of each of the four deoxynucleotide triphosphates, $1.5 \mathrm{~mm} \mathrm{MgCl} 2,50 \mathrm{~mm}$ $\mathrm{KCl}$, and $10 \mathrm{~mm}$ Tris- $\mathrm{HCl}(\mathrm{pH} 8.5)$, together with 6 pmoles of each primer. One nanogram of DNA and 0.8 units of 
Taq polymerase (a kind gift from the Center for Biotechnology, Rio Grande do Sul, Brazil) were then added, and the reaction mixture was overlaid with $20 \mu \mathrm{l}$ of mineral oil. The first cycle of amplification consisted of denaturation at $95^{\circ} \mathrm{C}$ for $5 \mathrm{~min}$, annealing at $30^{\circ} \mathrm{C}$ for $2 \mathrm{~min}$, and extension at $72^{\circ} \mathrm{C}$ for $3 \mathrm{~min}$. The second cycle was identical to the first, except that denaturation was at $92^{\circ} \mathrm{C}$ for 45 sec. The subsequent 33 cycles consisted of denaturation at $92^{\circ} \mathrm{C}$ for $45 \mathrm{sec}$, primer annealing at $40^{\circ} \mathrm{C}$ for $1 \mathrm{~min}$, and extension at $72^{\circ} \mathrm{C}$ for $2 \mathrm{~min}$. An additional $5 \mathrm{~min}$ at $72^{\circ} \mathrm{C}$ was included at the end of the program to ensure complete extension. For specific amplification, the same reaction mix was used except that 1 pmole of the primers and 0.4 units of Taq polymerase were used. The specific amplification cycle consisted of an initial denaturation at $94^{\circ} \mathrm{C}$ for $3 \mathrm{~min}$ followed by 30 cycles of amplification of $51^{\circ} \mathrm{C}$ for $2 \mathrm{~min}, 72^{\circ} \mathrm{C}$ for $2 \mathrm{~min}$, and $94^{\circ} \mathrm{C}$ for $30 \mathrm{sec}$, with an extended incubation at $72^{\circ} \mathrm{C}$ for $5 \mathrm{~min}$ in the final cycle. All amplified samples were subjected to electrophoresis using $4 \%$ polyacrylamide gels followed by silver staining. ${ }^{(10)}$

\section{RESULTS AND DISCUSSION}

To compare specific PCR and LS-PCR for Leptospira diagnosis, bacterial and host (hamster) DNAs were mixed and used as the amplification template. Under specific conditions, amplification results in a band of $\sim 280$ bp when Leptospira DNA is present (Fig. 1, lanes 2-6). In the absence of the bacterial DNA, the amplification is completely negative (Fig. 1, lane 1). In contrast, when LS-PCR is used, a relatively complex set of products results from both positive and negative samples that are distinguished by the presence or absence of the specific amplified band on the same background of LSPs (Fig. 1, lanes 7-12). Now, the absence of any amplified bands from an individual lane indicates failure of the PCR reaction owing, for example, to the omission of template DNA to the reaction mix (Fig. 1, lane 13). Using LS-PCR for diagnosis, the appropriate positive control is a tube known to contain the target DNA mixed with host DNA as shown in Figure 1, lane 10, for example. The presence of the specific band shows the inclusion of both primers in this tube, and the LSPs present define those that result from the LS-PCR amplifica-

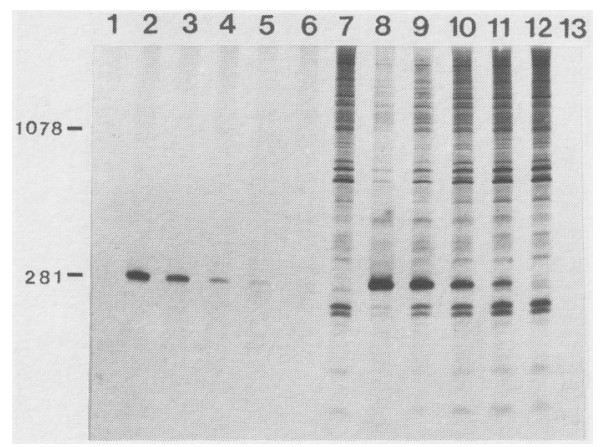

FIGURE 1 One nanogram of hamster DNA mixed with $200 \mathrm{pg}$ (lanes 2,8), $40 \mathrm{pg}$ (lanes $3,9), 8 \mathrm{pg}$ (lanes 4,10), $1.6 \mathrm{pg}$ (lanes 5,11), and $320 \mathrm{fg}$ (lanes 6,12) of $L$. interrogans serovar icterohaemorrhagiae DNAs were subjected to either specific PCR (lanes 1-6) or LS-PCR (lanes $7-12$ ) in 10- $\mu$ l reaction volumes and $3 \mu \mathrm{l}$ analyzed by electrophoresis through a $4 \%$ polyacrylamide gel and silver staining. (Lanes 1,7 ) Controls containing $1 \mathrm{ng}$ of hamster DNA alone; (lane 13) a negative control without either hamster or Leptospira DNA. The numbers at left indicate the positions of two reference DNA size markers.

tion of the host DNA by this primer pair. The presence of these LSPs in the other tubes then demonstrate the presence of both primers in each case. Minor differences would indicate polymorphisms between the individuals being tested, but the omission of a single primer would result in more than half the LSPs being different. ${ }^{(11)}$

The amplification of the specific band is favored in the first two rounds of LSPCR amplification because of the higher temperature at which the primers anneal to this region, ensuring that this interaction will take place prior to lower temperature annealing events. However, in subsequent rounds of amplification, there will be competition between the products potentially leading to a loss of sensitivity of LS-PCR in comparison with specific amplification. To test for this, decreasing amounts of Leptospira DNA were mixed with $1 \mathrm{ng}$ of hamster DNA and used for specific and LS-PCR as shown in Figure 1. We found that the effective cutoff point was in the region of $1 \mathrm{pg}$ of bacterial DNA. It can be observed that despite the concomitant amplification of LSPs the specific product tends to be more intense using LS-PCR than conventional conditions. At very low concentrations of specific template, the problem of distinguishing the specific band from LSPs begins to arise.
Thus, under these circumstances, although LS-PCR has the advantages stated in terms of providing an internal control, the presence of other bands may complicate the readout and confirmation by Southern blotting is advisable.

To directly test LS-PCR for diagnosis of acute experimental leptospirosis, serum samples were taken from seven hamsters, three of which were infected and four of which were uninfected, on the fourth day of infection. In a blind test all of the infected individuals were easily and correctly identified by a strong specific amplification band on an invariant background of LSPs that derive from hamster DNA present in the DNA samples (Fig. 2). Identical results were obtained with specific PCR (data not shown). In preliminary applications of this technique for clinical diagnosis, we are consistently using both specific and LS-PCR to have as much confidence as possible in the results. However, we have not come across a case, as yet, where LSPCR gave a negative result and specific PCR a positive result.

LS-PCR is probably applicable to the diagnosis of many diseases. It has the advantage of being immediately testable without the need for the construction of control templates, the production of alternative primers, or fundamental changes in protocol. The prerequisites for its application are simply that spe-

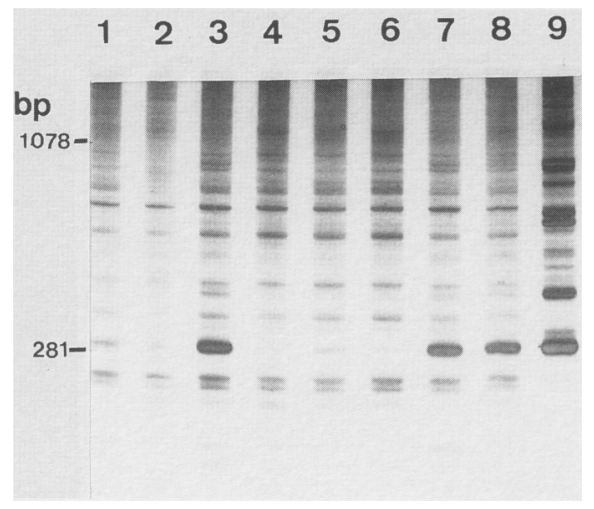

FIGURE 2 DNA samples prepared from the sera of seven hamsters (lanes 2-8), three of which were infected with $L$. interrogans serovar icterohaemorrhagiae (lanes $3,7,8$ ), were subjected to LS-PCR in $10-\mu$ leaction volumes and $3 \mu \mathrm{l}$ analyzed by electrophoresis through a $4 \%$ polyacrylamide gel and silver staining. (Lane 1) Amplification products from DNA extracted from the serum of an uninfected hamster; (lane 9) the products from DNA extracted from cultured $L$. interrogans serovar icterohaemorrhagiae. 
cific DNA primers are available and that the DNA is present in the biological samples being tested in sufficient concentrations to allow diagnosis by PCR. It thus should provide a useful methodology for any diagnostic laboratory.

\section{ACKNOWLEDGMENTS}

We thank Dr. Sérgio Pena for his encouragement and advice during the course of this work and his critical review of the manuscript. We also thank Mário Steindel for his various practical contributions to the execution of the work. The work was supported by CAPES, CNPq, and FIOCRUZ.

\section{REFERENCES}

1. Rodriguez, E.R., S. Nassim, J. Hsia, R.L. Sandin, A. Ferreira, B.A. Hilliard, A.M. Ross, and C.T. Garret. 1991. Cardiac myocytes and dendritic cells harbor human immunodeficiency virus in infected patients with and without cardiac dysfunction: Detection by multiplex, nested, polymerase chain reaction in individually microdissected cells from right ventricular endomyocardial biopsy tissue. Am. J. Cardiol. 68: 1511-1520.

2. Pallen, M.J., L.H. Puckley, and B.W. Brenden. 1992. A rapid, simple method for detecting PCR failure. PCR Methods Applic. 2: 91-92.

3. Dias Neto, E., F.R. Santos, S.D.J. Pena, and A.J.G. Simpson. 1993. Sex determination by low stringency PCR (LS-PCR). Nucleic Acids Res. 21: 763-764.

4. Welsh, J. and M. McClelland. 1990. Fingerprinting genomes using PCR with arbitrary primers. Nucleic Acids Res. 18: 7213-7218.

5. Williams, J.G.K., A.R. Kubelik, K.V. Livak, J.A. Rafalski, and S. Tingey. 1990. Fingerprinting genomes using arbitrary primers. Nucleic Acids Res. 18: 6531-6535.

6. Faine, S. 1982. In: Guidelines for the control of leptospirosis. WHO Offset Publication, WHO, Geneva, Switzerland.

7. Jonhson, R.C. and V.G. Harris. 1967. Differentiation of pathogenic and saprophytic leptospires I-Growth at low temperatures. J. Bacteriol. 94: 887-894.

8. Tamai, T., E. Sada, and Y. Kobayashi. 1988. Restriction endonuclease DNA analysis of $L$. interrogans serovars icterohaemorrhagiae and copenhageni. Microbiol. Immunol. 32: 877-894.

9. Gravekamp, C., H.V.D. Kemp, M. Franzen, D. Carrington, G.J. Schoone, G.J.J.M. Van Eys, C.O.R. Everard, R.A. Hartskeerl, and W.J. Terpstra. 1993. Detection of seven species of pathogenic leptospires by PCR using two sets of primers. J. Gen. Mi- crobiol. 139: 1691-1700.

10. Santos, E.R., S.D.J. Pena, and J.T. Epplen. 1993. Genetic and populational study of a Y-linked tetranucleotide repeat DNA polymorphism with a simple non-isotopic technique. Hum. Genet. 90: 655-656.

11. Welsh, J. and M. McClelland. 1991. Genomic fingerprinting using arbitrarily primed PCR with a matrix of pairwise combinations of primers. Nucleic Acids Res. 19: 5275-5279.

Received November 29, 1993; accepted in revised form February 14, 1994. 


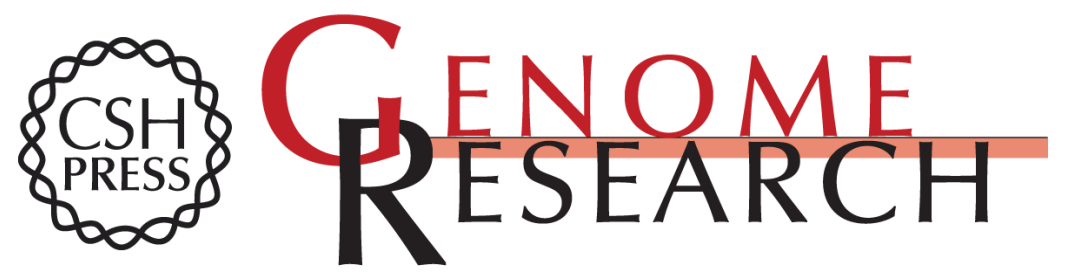

\section{Low-stringency PCR provides an internal control for negative results in PCR-based diagnosis.}

O L de Caballero, E Dias Neto, M C Koury, et al.

Genome Res. 1994 3: 305-307

\section{License}

Email Alerting Service

Receive free email alerts when new articles cite this article - sign up in the box at the top right corner of the article or click here.

\section{Affordable, Accurate Sequencing.}

